\title{
PATOFISIOLOGI NYERI (PAIN)
}

\author{
Mochamad Bahrudin \\ Fakultas Kedokteran Universitas Muhammadiyah Malang \\ J1. Bendungan Sutami No. 188A Malang
}

\author{
Email : Moch.bahrudin@yahoo.com
}

\begin{abstract}
ABSTRAK
Nyeri adalah pengalaman sensorik dan emosional yang tidak menyenangkan akibat kerusakan jaringan, baik aktual maupun potensial atau yang digambarkan dalam bentuk kerusakan tersebut.Mekanisme timbulnya nyeri didasari oleh proses multipel yaitu nosisepsi, sensitisasi perifer, perubahan fenotip, sensitisasi sentral, eksitabilitas ektopik, reorganisasi struktural, dan penurunan inhibisi. Antara stimulus cedera jaringan dan pengalaman subjektif nyeri terdapat empat proses tersendiri : tranduksi, transmisi, modulasi, dan persepsi.

Rangsang nyeri diterima oleh nosiseptor di kulit dan visera. Sel yang nekrotik akan melepaskan $\mathrm{K}^{+}$dan protein intrasel yang dapat mengakibatkan inflamasi. Mediator penyebab nyeri akan dilepaskan. Leukotrien, prostatglandin $\mathrm{E}_{2}$, dan histamine akan mensensitisasi nosiseptor selain itu lesi jaringan juga mengaktifkan pembekuan darah sehingga melepaskan bradikinin dan serotonin. Jika terdapat penyumbatan pembuluh darah, akan terjadi iskemia dan penimbunan $\mathrm{K}^{+}$dan $\mathrm{H}^{+}$ekstrasel yang diakibatkan akan semakin mengaktifkan nosiseptor yang telah tersensitasi. Perangsangan nosiseptor melepaskan substansi peptide $\mathrm{P}$ (SP) dan peptide yang berhubungan dengan gen kalsitonin (CGRP), yang meningkatkan respon inflamasi dan menyebabkan vasodilatasi serta meningkatkan permeabilitas vaskular.
\end{abstract}

Kata kunci : nyeri, nosiseptor

\begin{abstract}
Pain was a sensory and emotional experience of the unpleasant result of tissue damage, both actual and potential or described in terms of damage.The mechanism onset of pain was based on the multiple processes of nociception, peripheral sensitization, changes in phenotype, central sensitization, ectopic excitability, a structural reorganization, and decreased inhibition. Between stimulus and the subjective experience of tissue injury pain, there were four separate processes: tranduksi, transmission, modulation, and perception.

Nosiseptor pain stimuli received by the skin and viscera. Necrotic cells that will release $\mathrm{K}+$ and intracellular proteins that can cause inflammation. Mediators cause pain to be released. Leukotrienes, prostatglandin E2, and histamine will sensitization nosiseptor besides tissue lesions also activate blood clotting thus releasing bradykinin and serotonin. If there was a blockage of blood vessels, ischemia will occur and the accumulation of $\mathrm{K}+$ and $\mathrm{H}+$ was caused by extracellular will increasingly enable nosiseptor have sensitization. Stimulation nosiseptor releasing peptide substance P (SP) and peptide calcitonin gene-related (CGRP), which increases the inflammatory response and cause vasodilation and increased vascular permeability.
\end{abstract}

Keywords : pain, nosiseptor 


\section{PENDAHULUAN}

Nyeri adalah pengalaman sensorik dan emosional yang tidak menyenangkan akibat kerusakan jaringan, baik aktual maupun potensial atau yang digambarkan dalam bentuk kerusakan tersebut. Nyeri adalah suatu pengalaman sensorik yang multidimensional. Fenomena ini dapat berbeda dalam intensitas (ringan,sedang, berat), kualitas (tumpul, seperti terbakar, tajam), durasi (transien, intermiten,persisten), dan penyebaran (superfisial atau dalam, terlokalisir atau difus). Meskipun nyeri adalah suatu sensasi, nyeri memiliki komponen kognitif dan emosional, yang digambarkan dalam suatu bentuk penderitaan. Nyeri juga berkaitan dengan reflex menghindar dan perubahan output otonom (Meliala,2004).

Nyeri merupakan pengalaman yang subjektif, sama halnya saat seseorang mencium bau harum atau busuk, mengecap manis atau asin, yang kesemuanya merupakan persepsi panca indera dan dirasakan manusia sejak lahir. Walau demikian, nyeri berbeda dengan stimulus panca indera, karena stimulus nyeri merupakan suatu hal yang berasal dari kerusakan jaringan atau yang berpotensi menyebabkan kerusakan jaringan (Meliala,2004).

Bagi dokter, nyeri adalah suatu masalah yang membingungkan. Selain itu nyeri merupakan alasan tersering yang dikeluhkan pasien ketika berobat kedokter. Banyak institusi sekarang menyebut nyeri sebagai tanda vital kelima (fifth vital sign), dan mengelompokkannya bersama tandatanda klasik seprti : suhu, nadi, dan tekanan darah. Milton mengatakan "Pain is perfect miserie, the worst / of evil. And excessive, overture / All patience". Sudah menjadi kewajaran bahwa manusia sejak awal berupaya sedemikian untuk mengerti tentang nyeri dan mencoba mengatasinya (Bonica \& Loeser, 2001).

\section{Fisiologi Nyeri}

Mekanisme timbulnya nyeri didasari oleh proses multipel yaitu nosisepsi, sensitisasi perifer, perubahan fenotip, sensitisasi sentral, eksitabilitas ektopik, reorganisasi struktural, dan penurunan inhibisi. Antara stimulus cedera jaringan dan pengalaman subjektif nyeri terdapat empat proses tersendiri : tranduksi, transmisi, modulasi, dan persepsi.

Transduksi adalah suatu proses dimana akhiran saraf aferen menerjemahkan stimulus (misalnya tusukan jarum) ke dalam impuls nosiseptif.
Ada tiga tipe serabut saraf yang terlibat dalam proses ini, yaitu serabut A-beta, A-delta, dan C. Serabut yang berespon secara maksimal terhadap stimulasi non noksius dikelompokkan sebagai serabut penghantar nyeri, atau nosiseptor. Serabut ini adalah A-delta dan C. Silent nociceptor, juga terlibat dalam proses transduksi, merupakan serabut saraf aferen yang tidak bersepon terhadap stimulasi eksternal tanpa adanya mediator inflamasi.

Transmisi adalah suatu proses dimana impuls disalurkan menuju kornu dorsalis medula spinalis, kemudian sepanjang traktus sensorik menuju otak. Neuron aferen primer merupakan pengirim dan penerima aktif dari sinyal elektrik dan kimiawi. Aksonnya berakhir di kornu dorsalis medula spinalis dan selanjutnya berhubungan dengan banyak neuron spinal.

Modulasi adalah proses amplifikasi sinyal neural terkait nyeri (pain related neural signals). Proses ini terutama terjadi di kornu dorsalis medula spinalis, dan mungkin juga terjadi di level lainnya. Serangkaian reseptor opioid seperti mu, kappa, dan delta dapat ditemukan di kornu dorsalis. Sistem nosiseptif juga mempunyai jalur desending berasal dari korteks frontalis, hipotalamus, dan area otak lainnya ke otak tengah (midbrain) dan medula oblongata, selanjutnya menuju medula spinalis. Hasil dari proses inhibisi desendens ini adalah penguatan, atau bahkan penghambatan (blok) sinyal nosiseptif di kornu dorsalis.

Persepsi nyeri adalah kesadaran akan pengalaman nyeri. Persepsi merupakan hasil dari interaksi proses transduksi, transmisi, modulasi, aspek psikologis, dan karakteristik individu lainnya. Reseptor nyeri adalah organ tubuh yang berfungsi untuk menerima rangsang nyeri. Organ tubuh yang berperan sebagai reseptor nyeri adalah ujung syaraf bebas dalam kulit yang berespon hanya terhadap stimulus kuat yang secaara potensial merusak. Reseptor nyeri disebut juga Nociseptor. Secara anatomis, reseptor nyeri (nociseptor) ada yang bermiyelin dan ada juga yang tidak bermiyelin dari syaraf aferen. (Anas Tamsuri, 2006)

\section{Jalur Nyeri di Sistem Syaraf Pusat Jalur Asenden}

Serabut saraf $\mathrm{C}$ dan $\mathrm{A}$ delta halus, yang masing-masing membawa nyeri akut tajam dan kronik lambat, bersinap disubstansia gelatinosa kornu 
dorsalis, memotong medula spinalis dan naik ke otak di cabang neospinotalamikus atau cabang paleospinotalamikus traktus spino talamikus anterolateralis. Traktus neospinotalamikus yang terutama diaktifkan oleh aferen perifer A delta, bersinap di nukleus ventropostero lateralis (VPN) talamus dan melanjutkan diri secara langsung ke kortek somato sensorik girus pasca sentralis, tempat nyeri dipersepsikan sebagai sensasi yang tajam dan berbatas tegas. Cabang paleospinotalamikus, yang terutama diaktifkan oleh aferen perifer serabt saraf $\mathrm{C}$ adalah suatu jalur difus yang mengirim kolateral-kolateral ke formatio retikularis batang otak dan struktur lain. Serat-serat ini mempengaruhi hipotalamus dan sistem limbik serta kortek serebri (Price $A$. Sylvia,2006).

\section{Jalur Desenden}

Salah satu jalur desenden yang telah di identifikasi adalah mencakup 3 komponen yaitu :

a. Bagian pertama adalah substansia grisea periaquaductus (PAG) dan substansia grisea periventrikel mesenssefalon dan pons bagian atas yang mengelilingi aquaductus Sylvius.

b. Neuron-neuron di daerah satu mengirim impuls ke nukleus ravemaknus (NRM) yang terletak di pons bagian bawah dan medula oblongata bagian atas dan nukleus retikularis paragigantoselularis (PGL) di medula lateralis.

c. Impuls ditransmisikan ke bawah menuju kolumna dorsalis medula spinalis ke suatu komplek inhibitorik nyeri yang terletak di kornu dorsalis medula spinalis (Price A. Sylvia,2006). Untuk lebih jea[lasnya dapat dilihat pada gambar dibawah ini
- Transduction

- Transmission

- Modulation

- Perception

- Interpretation

- Behavior

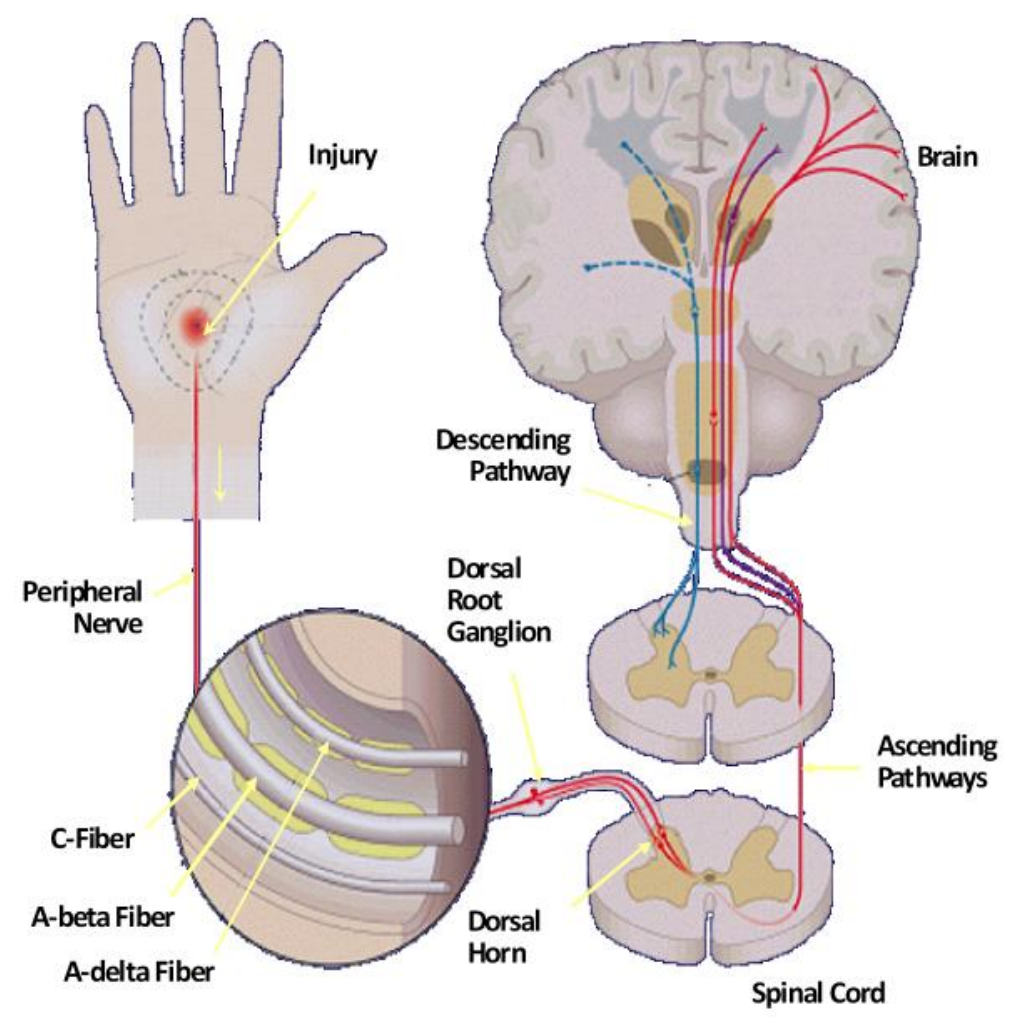

Gambar 1. Fisiologi Nyeri 


\section{Transmisi Nyeri}

Terdapat beberapa teori yang berusaha menggambarkan bagaimana nosiseptor dapat menghasilkan rangsang nyeri. Sampai saat ini dikenal berbagai teori yang mencoba menjelaskan bagaimana nyeri dapat timbul, namun teori gerbang kendali nyeri dianggap paling relevan. (Hartwig \& Wilson, 2005)

\section{a. Teori Spesivisitas (Specivity Theory)}

Teori ini digambarkan oleh Descartes pada abad ke 17. teori ini didasarkan pada kepercayaan bahwa terdapat organ tubuh yang secara khusus mentransmisi rasa nyeri. Syaraf ini diyakini dapat menerima rangsangan nyeri dan mentransmisikannya melalui ujung dorsal dan substansia gelatinosa ke talamus, yang akhirnya akan dihantarkan pada daerah yang lebih tinggi sehingga timbul respon nyeri. Teori ini tidak menjelaskan bagaimana faktor-faktor multi dimensional dapat mempengaruhi nyeri. (Hartwig \& Wilson, 2005)

\section{b. Teori Pola (Pattern Theory)}

Teori ini menerangkan bahwa ada dua serabut nyeri yaitu serabut yang mampu menghantarkan rangsang dengan cepat dan serabut yang mampu menghantarkan dengan lambat. Dua serabut syaraf tersebut bersinaps pada medula spinalis dan meneruskan informasi ke otak mengenai sejumlah intensitas dan tipe input sensori nyeri yang menafsirkan karakter dan kualitas input sensasi nyeri. (Hartwig \& Wilson, 2005)

\section{c. Teori Gerbang Kendali Nyeri ( Gate Control Theory )}

Tahun 1959 Milzack dan Wall menjelaskan teori gerbang kendali nyeri, yang menyatakan terdapat semacam pintu gerbang yang dapat memfasilitasi transmisi sinyal nyeri. (Hartwig \& Wilson, 2005)

Gate Control Theory merupakan model modulasi nyeri yang populer. Teori ini menyatakan eksistensi dari kemampuan endogen untuk mengurangi dan meningkatkan derajat perasaan nyeri melalui modulasi impuls yang masuk pada kornu dorsalis melalui "gate" (gerbang). Berdasarkan sinyal dari sistem asendens dan desendens maka input akan ditimbang. Integrasi semua input dari neuron sensorik, yaitu pada level medulla spinalis yang sesuai, dan ketentuan apakah gate akan menutup atau membuka, akan meningkatkan atau mengurangi intensitas nyeri asendens. Gate Control Theory ini mengakomodir variabel psikologis dalam persepsi nyeri, termasuk motivasi untuk bebas dari nyeri, dan peranan pikiran, emosi, dan reaksi stress dalam meningkatkan atau menurunkan sensasi nyeri. Melalui model ini, dapat dimengerti bahwa nyeri dapat dikontrol oleh manipulasi farmakologis maupun intervensi psikologis (painedu.org, 2008).

\section{Patofisiologi Nyeri secara Umum}

Rangsangan nyeri diterima oleh nociceptors pada kulit bisa intesitas tinggi maupun rendah seperti perennggangan dan suhu serta oleh lesi jaringan. Sel yang mengalami nekrotik akan merilis $\mathrm{K}+$ dan protein intraseluler. Peningkatan kadar $\mathrm{K}+$ ekstraseluler akan menyebabkan depolarisasi nociceptor, sedangkan protein pada beberapa keadaan akan menginfiltrasi mikroorganisme sehingga menyebabkan peradangan / inflamasi. Akibatnya, mediator nyeri dilepaskan seperti leukotrien, prostaglandin E2, dan histamin yang akan merangasng nosiseptor sehingga rangsangan berbahaya dan tidak berbahaya dapat menyebabkan nyeri (hiperalgesia atau allodynia). Selain itu lesi juga mengaktifkan faktor pembekuan darah sehingga bradikinin dan serotonin akan terstimulasi dan merangsang nosiseptor. Jika terjadi oklusi pembuluh darah maka akan terjadi iskemia yang akan menyebabkan akumulasi $\mathrm{K}+$ ekstraseluler dan $\mathrm{H}+$ yang selanjutnya mengaktifkan nosiseptor. Histamin, bradikinin, dan prostaglandin E2 memiliki efek vasodilator dan meningkatkan permeabilitas pembuluh darah. Hal ini menyebabkan edema lokal, tekanan jaringan meningkat dan juga terjadi Perangsangan nosisepto. Bila nosiseptor terangsang maka mereka melepaskan substansi peptida P (SP) dan kalsitonin gen terkait peptida (CGRP), yang akan merangsang proses inflamasi dan juga menghasilkan vasodilatasi dan meningkatkan permeabilitas pembuluh darah. Vasokonstriksi (oleh serotonin), diikuti oleh vasodilatasi, mungkin juga bertanggung jawab untuk serangan migrain . Peransangan nosiseptor inilah yang menyebabkan nyeri. (Silbernagl \& Lang, 2000)

Untuk lebih jelasnya lihat gambar dibawa ini . 


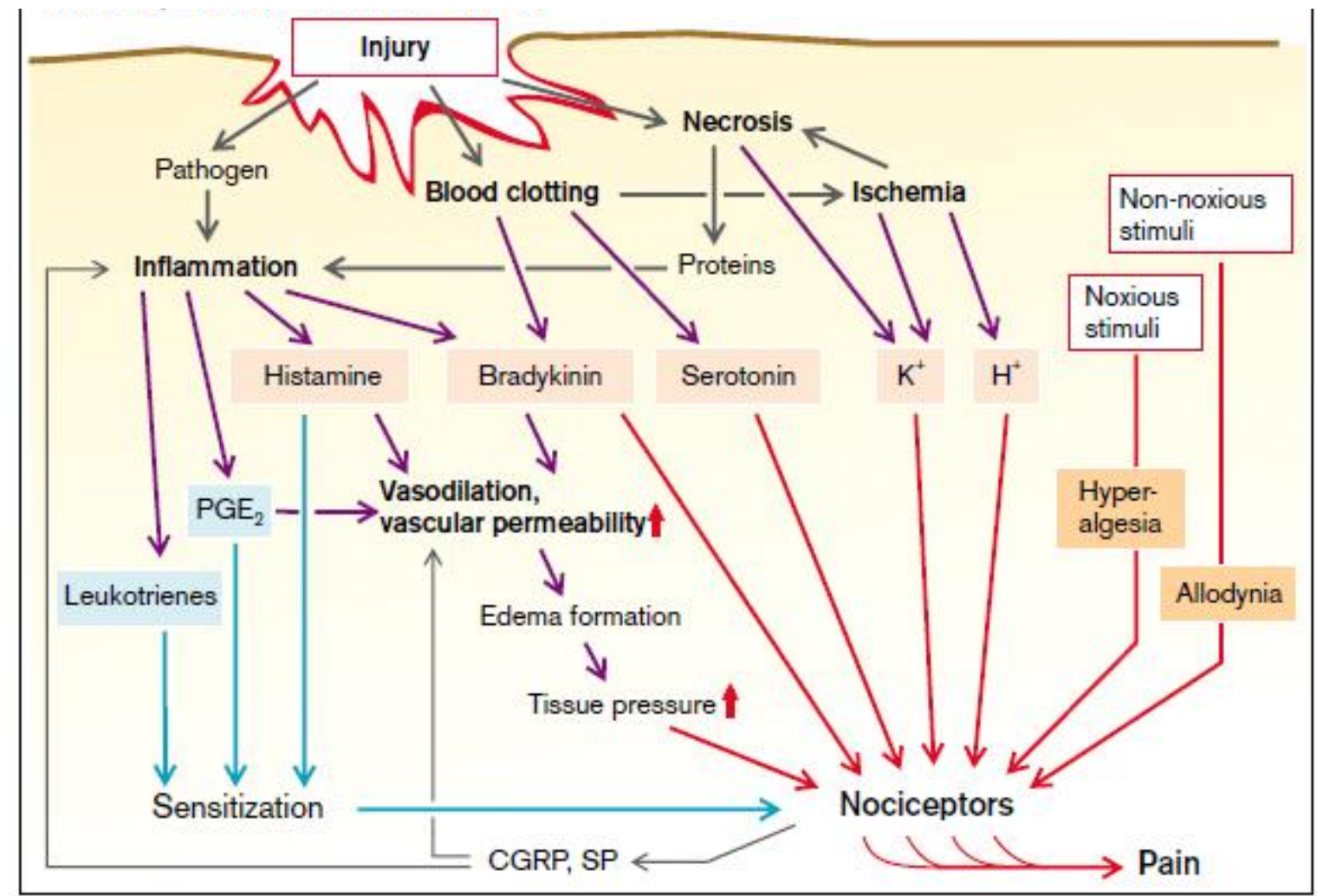

Gambar 2. Mekanisme nyeri perifer (Silbernagl \& Lang, 2000)

\section{Neuroregulator Nyeri}

Neuroregulator atau substansi yang berperan dalam transmisi stimulus saraf dibagi dalam dua kelompok besar, yaitu neurotransmitter dan neuromodulator. Neurotransmitter mengirimkan impuls-impuls elektrik melewati rongga sinaps antara dua serabut saraf, dan dapat bersifat sebagai penghambat atau dapat pula mengeksitasi. Sedangkan neuromodulator dipercaya bekerja secra tidak langsung dengan meningkatkan atau menurunkan efek partokular neurotransmitter. (Anas Tamsuri, 2006)

Beberapa neuroregulator yang berperan dalam penghantaran impuls nyeri antara lain adalah:

1. Neurotransmiter

a. Substansi P (Peptida)

Ditemukan pada neuron nyeri di kornu dorsalis (peptide eksitator) berfungsi untuk menstranmisi impuls nyeri dari perifer ke otak dan dapat menyebabkan vasodilatasi dan edema b. Serotonin

Dilepaskan oleh batang otak dan kornu dorsalis untuk menghambat transmisi nyeri.

c. Prostaglandin

Dibangkitkan dari pemecahan pospolipid di membran sel dipercaya dapat meningkatkan sensitivitas terhadap sel.

2. Neuromodulator

a. Endorfin (morfin endogen)

Merupakan substansi sejenis morfin yang disuplai oleh tubuh. Diaktivasi oleh daya stress dan nyeri. Terdapat pada otak, spinal, dan traktus gastrointestinal. Berfungsi memberi efek analgesik

b. Bradikinin

Dilepaskan dari plasma dan pecah disekitar pembuluh darah pada daerah yang mengalami cedera. Bekerja pada reseptor saraf perifer, menyebabkan peningkatan stimulus nyeri.Bekerja pada sel, menyebabkan reaksi berantai sehingga terjadi pelepasan prostaglandin. 


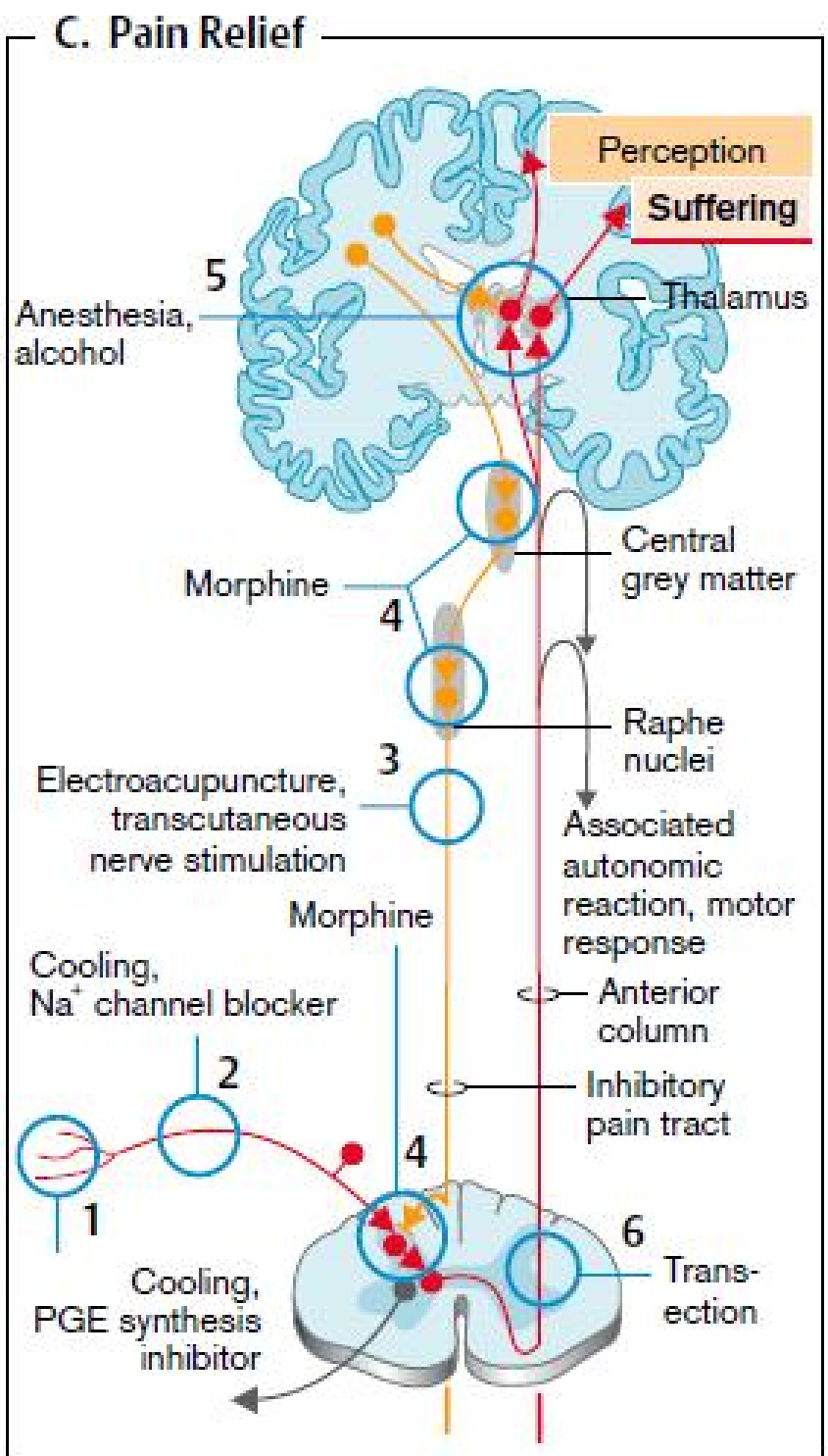

The impulses along the afferent nerves synapse in the spinal cord and pass via the anterolateral tracts to the thalamus and from there to, among others, the somatosensory cortex, the cingular gyrus, and the insular cortex $(\rightarrow C)$. Appropriate connections produce various components of pain sensation: sensory (e.g., perception of localization and intensity), affective (ailment), motor (protective reflex, muscle tone, mimicry), and autonomic (changes in blood pressure, tachycardia, pupillary dilatation, sweating, nausea). The connections in the thalamus and spinal cord are inhibited by the descending tracts from the cortex, midbrain periaqueductal gray matter, and raphe nucleus, these tracts employing norepinephrine, serotonin, and especially endorphines. Lesions of the thalamus, for example, can produce pain through an absence of these inhibitions (thalamus syndrome).

To counteract pain, the activation of pain receptors can be inhibited, for example, by cooling of the damaged area and by prostaglandin synthesis inhibitors $(\rightarrow \mathrm{C} 1)$. The transmission of pain can be inhibited by cooling and by $\mathrm{Na}^{+}$channel blockers (local anesthetics; $\rightarrow$ C2). Transmission in the thalamus can be inhibited by anesthesia and alcohol $(\rightarrow \mathrm{C} 5)$. Attempts have now and again been made to interrupt pain transmission by means of surgical nerve transection $(\rightarrow \mathrm{C} 6)$. Electroacupuncture and transcutaneous nerve stimulation act via activation of the descending, pain-inhibiting tracts $(\rightarrow \mathrm{C} 3)$. The endorphine receptors are activated by morphine and related drugs $(\rightarrow \mathrm{C} 4)$. Endogenous pain-inhibiting mechanisms can be aided by psychological methods of treatment.

An absence of pain brought about by pharmacological means or the very rare congenital condition of congenital analgesia interrupt these warning functions. If the cause of the pain is not removed, the consequences can be life-threatening.
Impuls sepanjang saraf aferen sinaps di sumsum tulang belakang dan lulus melalui anterolateral saluran ke talamus dan dari sana, antara lain, korteks somatosensori, yang Cingular gyrus, dan insular korteks (C!). Koneksi yang tepat memproduksi berbagai komponen sensasi nyeri: sensorik (Misalnya, persepsi lokalisasi dan intensitas), afektif (penyakit), motor (refleks pelindung, tonus otot, mimikri), dan otonom (perubahan di tekanan darah, takikardia, dilatasi pupil, berkeringat, mual). Sambungan di thalamus dan sumsum tulang belakang dihambat oleh yang turun saluran dari otak tengah, korteks periaqueductal abu-abu materi, dan rafe inti, ini traktat mempekerjakan norepinefrin, serotonin, dan terutama endorphines. Lesi thalamus, misalnya, dapat menghasilkan rasa sakit melalui tidak adanya hambatan ini (Sindrom talamus). Untuk mengatasi nyeri, pengaktifan rasa sakit reseptor dapat dihambat, misalnya, dengan pendinginan daerah yang rusak dan oleh prostaglandin inhibitor sintesis (C1). Transmisi nyeri dapat dihambat dengan pendinginan dan bloker kanal $\mathrm{Na}+$ (anestesi lokal; C2). Transmisi di thalamus dapat dihambat oleh anestesi dan alkohol (! C5). Upaya telah nowand lagi beenmade untuk mengganggu nyeri transmisi dengan cara bedah saraf transeksi (C6). Electroacupuncture dan saraf transkutaneus stimulasi tindakan melalui 
aktivasi, turun rasa sakit menghambat saluran (C3). Reseptor endorphine yang diaktifkan oleh morfin dan obat terkait (C4). Endogen sakit menghambat mekanisme dapat dibantu dengan metode psikologis pengobatan. Tidak adanya rasa sakit yang dibawa oleh farmakologi berarti atau kongenital sangat jarang mengganggu kondisi analgesia bawaan fungsi-fungsi peringatan. Jika penyebab nyeri tidak dihilangkan, konsekuensinya dapat mengancam jiwa.

\section{DAFTAR PUSTAKA}

Asdie, Ahmad H. 1999. Harrison Prinsip-prinsip ilmu penyakit dalam. Jakarta: EGC

Beydoun, A., Kutluay, E. 2002. Oxcarbazepin, Expert Opinion in Pharmacotherapy, 3(1):59-71

Bonica, J.J., Loeser, J.D., 2001. History of Pain Concepts and Therapies, In: Loeser J.D., et al (eds)

Bonica's , 2001, Management of Pain. Lippincott William \& Wilkins Philadelphia, pp 3-16

Meliala, L. 2004. Nyeri Keluban yang Terabaikan: Konsep Dahulu, Sekarang, dan Yang Akan Datang, Pidato Pengukuhan Jabatan Guru Besar, Fakultas Kedokteran Universitas GadjahMada.

Painedu.org, 2008. Physiology of Pain, http:// www.painedu.org.

Silbernagl/Lang, 2000, Pain in Color Atlas of Pathophysiology, Thieme New York. 320-321

Price, Sylvia Anderson. 2006. Patofisiologi. Jakarta: EGC

Tansumri, Anas. 2007. Konsep dan Penatalaksanaan Nyeri. Jakarta: EGC 